\title{
Canopy fuel characteristics and potential crown fire behavior in Aleppo pine (Pinus halepensis Mill.) forests
}

\author{
Ioannis D. Mitsopoulos*, Alexandros P. DiMITRAKopoulos \\ Laboratory of Forest Protection, School of Forestry and Natural Environment, Aristotle University of Thessaloniki, PO Box 228,
} 54124 Thessaloniki, Greece

(Received 4 July 2006; accepted 27 September 2006)

\begin{abstract}
Canopy fuel characteristics that influence the initiation and spread of crown fires were measured in representative Aleppo pine (Pinus halepensis Mill.) stands in Greece. Vertical distribution profiles of canopy fuel load, canopy base height and canopy bulk density are presented. Aleppo pine canopy fuels are characterized by low canopy base height $(3.0-6.5 \mathrm{~m})$, while available canopy fuel load $\left(0.96-1.80 \mathrm{~kg} / \mathrm{m}^{2}\right)$ and canopy bulk density $\left(0.09-0.22 \mathrm{~kg} / \mathrm{m}^{3}\right)$ values are similar to other conifers worldwide. Crown fire behavior (probability of crown fire initiation, crown fire type, rate of spread, fireline intensity and flame length) in Aleppo pine stands with various understory fuel types was simulated with the most updated crown fire models. The probability of crown fire initiation was high even under moderate burning conditions, mainly due to the low canopy base height and the heavy surface fuel load. Passive crown fires resulted mostly in uneven aged stands, while even aged stands gave high intensity active crown fires. Assessment of canopy fuel characteristics and potential crown fire behavior can be useful in fuel management and fire suppression planning.
\end{abstract}

canopy fuels / crown fires / fire behavior / Aleppo pine (Pinus halepensis Mill.) / Mediterranean Basin

Résumé - Caractéristiques des combustibles de la canopée et comportement du potentiel de feu des couronnes de forêts de Pin d'Alep (Pinus halepensis Mill.). Les caractéristiques des combustibles qui influencent le démarrage et la propagation des feux de couronnes ont été mesurées dans des peuplements représentatifs de Pinus halepensis Mill. en Grèce. Des profils verticaux de la charge en combustible de la canopée, la hauteur de la base de la canopée et la densité volumique de la canopée sont présentés. La charge combustible de la canopée est caractérisée par une faible hauteur de la base de la canopée $(3,0-6,5 \mathrm{~m})$, tandis que la charge en combustible disponible $\left(0,96-1,80 \mathrm{~kg} / \mathrm{m}^{2}\right)$ et la densité volumique de la canopée $\left(0,09-0,22 \mathrm{~kg} / \mathrm{m}^{3}\right)$ sont similaires à celles des autres conifères dans le monde. Le comportement du feu de couronne (probabilité de démarrage du feu dans les couronnes, type de feu de couronne, taux de propagation, intensité de la ligne de feu et longueur des flammes) dans les peuplements de Pinus halepensis avec différents types de combustibles de sous-bois a été simulé avec le maximum de modèles actuels de feux de couronnes. La probabilité de démarrage de feu de couronne était forte même en conditions de faible embrasement, principalement en relation avec la faible hauteur de la base des couronnes et la forte charge en combustible au sol. Des feux passifs de couronnes se produisent principalement dans les peuplements inéquiennes tandis que les peuplements équiennes ont présenté de fortes intensités de feux actifs de couronnes. L'évaluation des caractéristiques des combustibles de la canopée et le comportement du potentiel de feu peuvent être très utiles pour la gestion des combustibles et la planification de la lutte contre les feux.

combustibles de la canopée / feux de couronnes / comportement du feu / Pinus halepensis Mill. / bassin méditerranéen

\section{INTRODUCTION}

Wildland fires are the most destructive disturbance of the natural lands in the Mediterranean Basin. Mediterranean landscapes have always been subjected to fire and, thus, burning became part of their dynamic natural equilibrium [57]. Recent changes in land-use patterns in the Mediterranean Basin have caused the reduction or abandonment of traditional activities, such as extensive grazing or wood harvesting. This resulted in the increase of the amount of fuel available for burning [61]. Aleppo pine (Pinus halepensis Mill.) forests cover approximately 2500000 ha in the Mediterranean Basin, mostly at low elevations (less than $500 \mathrm{~m}$ ) and along the coastline. These forests are particularly prone to fires and represent approximately $1 / 3$ of the total annual burned area in the Mediterranean Basin [64]. The dense broadleaved-evergreen shrub understory

* Corresponding author: ioanmits@ for.auth.gr (known as "maquis") below the live crown fuel layer creates ladder fuels that facilitate fire transition from the forest ground to the canopy layer [77]. The Aleppo pine forests of Greece (which cover $8.72 \%$ of the total forested area) grow under more arid conditions than those of the West Mediterranean, thus resulting in increased fire frequency and intensity [14]. During a 17 year period (1980-1996), 11.15\% of total fires in Greece occurred in Aleppo pine forests, burning 83410 ha (approximately $16 \%$ of the total burned area). On the average, $2.85 \%$ of the total Aleppo pine forested area is burnt in Greece every year [26].

Crown fires are very complex phenomena. They usually occur under extreme fire weather conditions, resulting in erratic and dangerous fire behavior. After crowning, fires have been observed to increase their rate of spread, intensity and spotting activity [8]. Crown fires are virtually impossible to control by direct action [5]. They are also responsible for the largest 
proportion of the overall area burned in large fires in coniferous forests, worldwide $[2,36]$. The importance of crown fire behavior prediction in assessing fire potential has made it a prerequisite for evaluating the effectiveness of fuel management treatments during fire prevention planning [33,44,70,72].

Fire behavior models implemented in fire management decision support systems require accurate descriptions of fuel complex characteristics. Until recently, fuel complex characterization has been limited to surface fuel beds [10,27], due to the restricted applicability of fire behavior simulation models only to surface fuels $[11,16]$. The development of fire behavior models and systems designed to predict crown fire behavior $[24,25,31,32,70,79,80]$ made necessary the measurement of canopy fuel data. Recently, the risk of wildland fire as a forest stand management optimization problem was analyzed [34, 35].

The objective of this study was to measure the critical canopy fuel characteristics (canopy fuel load, canopy bulk density, canopy base height) of Aleppo pine forests in Greece and, subsequently, assess their potential crown fire behavior by simulation with the most recent crown fire simulation models.

\section{BACKGROUND}

\subsection{Canopy fuels}

When describing aerial fuels, the terms "crown" and "canopy" are often used interchangeably without formal distinction. In recent studies, the term "crown" is applied to describe aerial fuels at the tree level and "canopy" at the stand level [23]. Computer systems and models that simulate crown fire behavior need a quantitative description of the canopy fuels; available canopy fuel load (CFL), canopy bulk density $(\mathrm{CBD})$ and canopy base height $(\mathrm{CBH})[31,32,70]$.

\subsection{1. $C F L$}

As available CFL is considered only the part of the total aerial fuels that is consumed by a crown fire. Since conifer needles are the main aerial fuels consumed during a crown fire [79], crown fuel properties are based on the quantification of live needle foliage. Nevertheless, current research efforts state that in certain fuel complexes, other fuel categories, such as the fine twigs, may significantly contribute to the heat released from the flaming zone of a crown fire $[19,70,76]$. Although numerous studies correlate crown or foliage biomass with tree dendrometric characteristics $[13,37,46,51,53,55,56]$, only few studies measure crown fuel load by diameter size class at tree level $[15,39,40,73]$ and at stand level $[9,23]$, as it is required in crown fire behavior modeling.

\subsection{2. $C B D$}

CBD, measured in $\mathrm{kg} / \mathrm{m}^{3}$, is the dry weight of the available canopy fuel load per unit of canopy volume [70]. CBD is a target value for assessing the spread of active crowning in conifer stands $[44,70]$. Agee [1] analyzed post fire data from several stands and identified a CBD threshold of $0.10 \mathrm{~kg} / \mathrm{m}^{3}$, below which active crown fire spread is greatly limited. This threshold value is also supported by Alexander [7] and Cruz et al. [25], in detailed wildfire case-studies analysis. Johnson [42] considers a CBD of $0.05 \mathrm{~kg} / \mathrm{m}^{3}$ as a critical threshold value for active crown fire development. CBD is difficult to measure because it requires detailed knowledge of the vertical distribution of crown fuel biomass. For uniform stands, CBD can be computed as the available canopy fuel load divided by canopy depth $[1,6,23,33,42]$. This method carries the implicit assumption that canopy biomass is distributed uniformly within the stand canopy, which is unlikely to be true even in stands with very simple structure; multi-storied stands are probably even more poorly represented by this procedure [70]. To overcome this assumption, Scott and Reinhardt [70], approached the estimation of CBD by dividing the stand in layers of $0.3 \mathrm{~m}$ depth and, subsequently, by defining as "effective" CBD the maximum value of the CBD computed from the $4.5 \mathrm{~m}$ running mean of the fuel layers starting from the base to the top of the canopy. Alexander et al. [9] distributed the canopy fuel weight vertically for each crown fuel component using the fraction of the total canopy fuel weight by crown segment as a function of the total crown height. Keane et al. [43] estimated CBD using six groundbased methods with several optical instruments, estimating Leaf Area Index (LAI). LAI was converted to an estimate of crown fuel biomass using specific leaf area factors. Several authors have estimated CBD using remote sensing methods and lidar data $[65,66]$.

\subsection{3. $\mathrm{CBH}$}

$\mathrm{CBH}$ is not well defined or easy to estimate at a stand level. One of the main problems is the lack of a universally accepted definition for the lower limit of the canopy fuel layer [23]. Several authors $[23,45,52,79]$ consider as $\mathrm{CBH}$ the distance from the forest floor to the live crown base. Wilson and Baker [83] used the midpoint between the minimum $\mathrm{CBH}$ from the ground and the average live crown height for calculating crown fire initiation risk in multi-layered stands. Sando and Wick [69] defined the CBH as the canopy's lowest vertical section with CBD greater than $0.037 \mathrm{~kg} / \mathrm{m}^{3}$. Williams [82] considered this threshold as too low and suggested a value of $0.067 \mathrm{~kg} / \mathrm{m}^{3}$. Scott and Reinhardt [70], defined CBH as the lowest height above the ground at which there is sufficient canopy fuel to propagate fire vertically through the canopy. Sufficient canopy fuel was arbitrarily defined by these authors as $0.011 \mathrm{~kg} / \mathrm{m}^{3}$. Ottmar et al. [59] defined $\mathrm{CBH}$ as the height from the ground to the lowest continuous branches of the tree canopy and identified ladder fuels as the height of the lowest live or dead branch material that could carry fire into the crown. Cruz et al. [24] used the term FSG (Fuel Strata Gap) to define the distance from the top of the surface fuelbed to the lower limit of the canopy fuel layer constituted by live needles and ladder fuels that can sustain vertical fire propagation. Cruz [21] defined the critical canopy bulk density value for vertical fire propagation into the canopy layer as $0.05 \mathrm{~kg} / \mathrm{m}^{3}$, based in the analysis of a large experimental fire dataset, where evidence of crown fire activity was observed in stands with canopy bulk densities greater than $0.04 \mathrm{~kg} / \mathrm{m}^{3}$.

\subsection{Crown fire behavior modeling}

Crown fire modeling depends on two basic procedures: the analysis of surface to crown fire transition and the study of crown fire rate of spread [21]. An extensive review of the existing crown fire models can be found in Pastor et al. [60]. 


\subsubsection{Crown fire initiation}

Modeling the initiation of crown fires has mainly followed a semiempirical approach. This has lead to models suitable for implementation in operational fire modeling systems [7,79,84]. Van Wagner [79] stated that crown foliage ignites when heat from a surface fire dries it and raises it to ignition temperature. The model determines the critical surface fireline intensity needed to induce crown combustion as a function of the crown base height, foliar moisture content and a coefficient $\mathrm{C}$. This coefficient was derived from field observations during a single fire and is regarded as "an empirical constant of complex dimensions" [79]. Van Wagner's model has been used as the basis for crown fire initiation in computer programs used for wildfire prediction such as the BEHAVE [16], FARSITE fire area simulator model [31] and NEXUS crown fire hazard assessment system [70]. Xanthopoulos [84], through laboratory experiments, measured the critical temperature for foliage ignition in the convection plume of a surface fire. He developed equations to predict time-temperature profiles at different heights in the convection plume and time-to-ignition equations for the foliage of Pinus ponderosa, Pinus contorta and Pseudotsuga menziesii. Alexander [7] developed an algorithm to predict the onset of crowning through the estimation of the convection plume angle and the calculation of the temperature increase above the ambient temperature at the base of the crown of Pinus radiata plantations in Australia. Cruz et al. [24] modeled the likelihood of crown fire initiation based on a large experimental fire data set. An empirical logistic model was developed to predict the onset of crowning as a function of wind speed, fuel strata gap, moisture content of fine dead fuels and surface fuel consumption. The model was evaluated against data from two experimental burn projects (eighteen experimental fires in total) with encouraging results. Theoretical modeling efforts $[38,48,63]$ for crown fire development are restrained by limitations in the understanding of the physical and chemical processes that take place during combustion [60].

\subsubsection{Crown fire spread}

Van Wagner [79] analyzed the conditions for crown fire spread on the basis of the net horizontal heat flux, the canopy bulk density and the heat of ignition. According to Van Wagner [79] theory, a crown fire will spread horizontally only if the horizontal heat flux supplied to the crown fuel ahead of the fire and the mass flow rate of the fuel into the crown space, exceed a minimum rate. He further recognized three types of crown fires: passive, active, and independent, according to whether the crown fire is dependent upon heat supplied from the surface fire, or is spreading simultaneously with the surface fire, or is spreading independently from the surface fire. Independent crown fire propagation very rarely occurs in nature [81]. The critical minimum rate of spread for active crowning is associated with the minimum mass flow rate of the fuel for the development of a continuous flame front both in the surface and in the canopy layer, as expressed by the ratio of the critical mass flow rate and CBD. Van Wagner [79] has empirically determined from experimental fires carried out in a $\mathrm{Pi}$ nus banksiana plantation, the critical mass flow rate to approximately $3 \mathrm{~kg} / \mathrm{m}^{2} / \mathrm{min}$.

Rothermel [68] obtained a statistical correlation for crown fire rate of spread by observing and analyzing eight large wildfires in the Northern Rocky Mountains. Using his surface fire prediction model [67], he estimated that crown fire rate of spread was 3.34 times faster than that predicted from his surface fire model using fuel model 10 (timber, litter and understory) [10]. Van Wagner [80, 81] developed a semi-empirical procedure for obtaining the rate of spread of active and passive crown fires in Canadian conifer plantations. $\mathrm{He}$ chose this kind of vegetation because of its clear stratification and its low fuel arrangement variability compared with naturally regenerated areas. Although Rothermel's [68] and Van Wagner's [80, 81] models have empirical character and present various assumptions and limitations, nevertheless they have been incorporated in most wildland fire predictions systems such as the Canadian Forest Fire Prediction System [32], FARSITE [31], NEXUS [70] and BehavePlus version 3 [12]. Cruz et al. [22,25] modeled crown fire rate of spread through non-linear regression analysis based on an experimental dataset which covered a broad spectrum of fuel complexes and fire behavior characteristics. The active crown rate of spread model was created as a function of wind speed, fine fuel moisture content and CBD.

Several theoretical models to predict crown fire spread are found in the literature $[3-5,17]$. These models are based on Albinis' fire spread model [3] which simplistically assumes that radiation is the only heat transfer mode during wildland fires. Another disadvantage of these models is that the complexity of physical modeling and the heat transfer numerical analysis leads to large computation times, thus limiting their operational implementation. Recently, Dupuy and Morvan [30] provided a multiphase physical model of fire behavior and run two-dimensional numerical simulations of crown fire propagation in pine stands. Also, Linn et al. $[49,50]$ presented FIRETEC, a three dimensional coupled atmospheric/wildfire behavior model based on transport equations. These two models are presently often used to simulate wildfire behavior.

\subsubsection{The International Crown Fire Modelling Experiment}

The primary objective of the International Crown Fire Modelling Experiment (ICFME) was the testing and calibration of a newly developed, physically based model for predicting the rate of spread and the flame front intensity of crown fires in conifer forests [17]. Furthermore, all the existed fully operational models were evaluated against high intensity experimental crown fires [76]. The experimental dataset was comprised of eleven experimental crown fires in a mature Pinus banksiana stand with a substantial Picea mariana understory. The Rothermel [68] and Van Wagner [81] models were found to seriously under-predict the spread rate of the experimental fires. The new physical model overestimated the crown fire rate of spread and required large computation time. On the contrary, the Cruz et al. [22,25] model adequately predicted the crown fire rate of spread in most cases [76]. The ICFME is the only extensive evaluation of crown fire models published so far.

\subsection{Methods}

\subsubsection{Study area}

The study area is located at the central part of the Kassandra peninsula of Chalkidiki in Northern Greece ( $\left.23^{\circ} 40^{\prime} \mathrm{N}, 38^{\circ} 55^{\prime} \mathrm{W}\right)$. This area has been chosen because it is representative of coastal Aleppo pine forests in Greece. The mean altitude is approximately $200 \mathrm{~m}$ and the climate of the area is of the Mediterranean type, with mild winters 
Table I. Descriptive statistics of Aleppo pine sampled trees.

\begin{tabular}{lcccccc}
\hline & $\begin{array}{c}\text { Diameter at breast } \\
\text { height }(\mathrm{cm})\end{array}$ & Height $(\mathrm{m})$ & Age (years) & $\begin{array}{c}\text { Live crown } \\
\text { length }(\mathrm{m})\end{array}$ & $\begin{array}{c}\text { Height to live } \\
\text { crown base (m) }\end{array}$ & Crown width (m) \\
\hline Minimum & 7 & 5 & 12 & 3.5 & 0.5 & 1.4 \\
Maximum & 56 & 24 & 54 & 18 & 9.5 & 10.8 \\
Range & 49 & 19 & 42 & 14.5 & 9 & 9.4 \\
Mean & 28.9 & 13.2 & 30.8 & 10.1 & 3.1 & 4.8 \\
Standard deviation & 14.2 & 5.2 & 12.8 & 3.4 & 2.4 & 3.3 \\
Standard Error & 2.2 & 0.8 & 2.1 & 0.5 & 0.4 & 0.5 \\
N & 40 & 40 & 40 & 40 & 40 & 40 \\
\hline
\end{tabular}

and dry hot summers. The mean annual rainfall reaches $560.4 \mathrm{~mm}$, while the mean annual air temperature is $16.5^{\circ} \mathrm{C}$. In the past, numerous fires have burned different parts of these forests. The forest vegetation is comprised of dominant Aleppo pine (Pinus halepensis Mill.) stands and, in most cases, there is a dense understory of broadleaved-evergreen shrubs (maquis).

\subsubsection{Fuel and stand measurements}

Destructive sampling of 40 trees was conducted over the sampling site during the summer. The sampled trees were selected from various uneven and even aged stands, to represent the full range of tree sizes in the forest. Trees extremely lopsided in the crown, heavily defoliated and broken topped were excluded [15].

For each sampled tree, diameter at breast height (DBH) was measured to the nearest $\mathrm{mm}$. After felling, the tree's age was measured and measurements of total height, height from ground to live crown and crown length were taken to the nearest decimeter. The stem of each sampled tree was cut into one meter sections starting from crown apex and the available crown fuel load (needles and branches $<0.63 \mathrm{~mm}$ ) was weighed the day the tree was cut to minimize water loss. It should be recognized that after felling, the relative position of some of the branches to the tree stem (i.e., angle of insertion) may have changed, when the trees hit the ground. This may have resulted in a slight change in the canopy fuel profile, as it was initially in the standing position of the trees. Table I presents descriptive statistics of the sampled trees used in the analysis. After weighing the available crown fuel components in the field, samples were taken in the laboratory for moisture content determination. Fuel moisture content was determined by oven-drying at $105{ }^{\circ} \mathrm{C}$ for $48 \mathrm{~h}$.

In order to study the structure characteristics of different Aleppo pine stands, 10 sample plots of $500 \mathrm{~m}^{2}$ each were randomly taken in representative forest stands. In every plot, the DBH of every tree was measured. Total height and height to live crown base were measured with a Haga altimeter. Canopy closure in each plot was estimated using a spherical densiometer [47]. The data were analyzed statistically to define stand inventory data.

\subsubsection{Canopy fuel profiles}

A similar approach to Alexander et al. [9] was followed in order to construct the vertical distribution profile of the available crown fuel load; starting from the crown apex of every sampled tree, the cumulative ratio (RW) of the dry weight of each one meter section to the total weight of every crown fuel component (needles and branches $<0.63 \mathrm{~cm}$ ) was calculated. The ratio of the relative height $(\mathrm{RH})$ of each one meter section to the total height of the tree was also obtained. These two variables, with values between 0 and 1 , were fitted to the following three parameter logistic model [9]:

$$
R W=a / 1+\exp [b-c(R H)]
$$

The vertical fuel profiles were constructed by sectioning all the trees of each plot in 1-m horizontal layers from the ground to the apex of the tallest tree. The variable RW of each available crown fuel component was calculated for each 1-m height section in every sampled plot. This cumulative value was transformed into the fraction of the total dry weight per section and multiplied by the total dry weight of the corresponding available crown fuel component to obtain sectional dry weight. The total available crown fuel weight for each tree in every plot was estimated using species - specific crown fuel allometric equations for Aleppo pine in Greece [54]. The results, summed over the stem density and converted into $\mathrm{kg} / \mathrm{m}^{2}$, resulted in the vertical distribution of the available canopy fuel load per plot. Effective canopy bulk density was estimated according to Scott and Reinhardt [70], as described previously. Canopy base height was defined as the lowest height above ground with CBD of at least $0.04 \mathrm{~kg} / \mathrm{m}^{3}$ [21].

\subsubsection{Modeling crown fire behavior}

Potential crown fire behavior was simulated using Cruz et al. $[24,25]$ crown fire initiation and spread models, with input data the canopy and surface fuel load values of each plot. The type of fire (active crown fire or passive crown fire) was assessed by Van Wagner's [79] criterion for active crown fire spread. Available surface fuel loads are required to run the crown fire initiation model [24]. For this, surface fuel models, typical of the understory vegetation of Aleppo pine forests (pine litter, evergreen-sclerophyllous shrublands up to $1.5 \mathrm{~m}$ and evergreen-sclerophyllous shrublands $1.5-3.0 \mathrm{~m}$ height), were used as surface fuelbeds during the fire simulation [27]. Low burning conditions were set to fine fuel moisture of $14 \%$ and $10 \mathrm{~km} / \mathrm{h}$ windspeed, moderate burning conditions to fine fuel moisture of $10 \%$ and $20 \mathrm{~km} / \mathrm{h}$ windspeed, while extreme burning conditions were set to fine fuel moisture of $6 \%$ and $30 \mathrm{~km} / \mathrm{h}$ windspeed. All the wind values refer to $10-\mathrm{m}$ open windspeeds. Fireline intensity was estimated by Byram's equation [18]. Crown fire intensity was calculated by adding the available canopy fuel load to the available surface fuel load. As available surface fuel load was considered the litter, the live foliage and the live and dead branches with diameter less than $2.5 \mathrm{~cm}$. 
Table II. Regression models of the vertical canopy fuel distribution of Aleppo pine stands ${ }^{\mathrm{a}}$.

\begin{tabular}{lcccccc}
\hline Crown Fuel Component & a (A.S.E.) & b (A.S.E.) & c (A.S.E.) & $R^{2}$ & M.S.E. & C.V. (\%) \\
\hline Needles & $1.045(0.0156)$ & $4.925(0.166)$ & $8.055(0.315)$ & 0.93 & 0.091 & 17.8 \\
$0.0-0.63 \mathrm{~cm}$ & $1.059(0.0192)$ & $4.742(0.163)$ & $7.131(0.335)$ & 0.90 & 0.107 & 22.8 \\
\hline
\end{tabular}

${ }^{a}$ Model form: $R w=a /[1+\exp (b-c R h)], R w$ : the cumulative ratio of the dry weight of each $1-\mathrm{m}$ section to the total weight of every crown fuel component (needles and branches $<0.63 \mathrm{~cm}$ ), Rh: the ratio of the relative height of each $1-\mathrm{m}$ section to the total height of every tree, A.S.E.: asymptotic standard error, $R^{2}$ : coefficient of determination, M.S.E.: mean square error, C.V.: coefficient of variation.

Surface fuel consumption by the fire was adjusted to $90 \%, 60 \%$ and $30 \%$ of the total load, representing extreme, moderate and low burning conditions, respectively. Heat content values for all simulations were obtained from Dimitrakopoulos and Panov [28]. Crown fire flame length was estimated by Thomas' flame length equation [78]. All crown fire behavior predictions refer to level terrain and are valid only for active crown fires.

The statistical analysis was performed with SPSS (version 12.0) statistical package [58].

\section{RESULTS}

Table II presents the coefficients of the three-parameter model used in the statistical analysis of the sampled trees in order to develop the vertical canopy fuel distribution for Aleppo pine trees. The model equations explained respectively $93 \%$ and $90 \%$ of the variation in the vertical distribution in needles and fine branches $(0.0-0.63 \mathrm{~cm}$ in diameter), and were highly statistically significant ( $p<0.0001)$. Coefficient of variation was $17.8 \%$ for needles and $22.8 \%$ for the branches with diameter $<0.63 \mathrm{~cm}$.

The CFL distributions of the overstory tree canopies of Aleppo pine sampled plots are generally similar (Figs. 1, 2). Effective CBD (4-m maximum running mean) was located at the mid-canopy level in all plots (Figs. 3, 4). The principal difference among the plots was the variation in $\mathrm{CBH}$; stands with uneven aged structure had lower values of $\mathrm{CBH}$, due to the presence of small trees in the middlestory. Stand inventory data and canopy fuel characteristics for all sampled plots are shown in Table III. Aleppo pine effective CBD (4-m maximum running mean) values ranged from 0.09 to $0.22 \mathrm{~kg} / \mathrm{m}^{3}$, CFL from 0.96 to $1.80 \mathrm{~kg} / \mathrm{m}^{2}$ and $\mathrm{CBH}$ from 3 to $6.5 \mathrm{~m}$. Lower values in canopy fuel characteristics were measured in uneven aged stands, where effective CBD ranged from 0.09 to $0.20 \mathrm{~kg} / \mathrm{m}^{3}$ (mean: $0.13 \mathrm{~kg} / \mathrm{m}^{3}$ ) and $\mathrm{CBH}$ from 3 to $5 \mathrm{~m}$. (mean: $3.8 \mathrm{~m}$ ). On the contrary, even aged stands presented higher canopy fuel values; CBD ranged from 0.15 to $0.22 \mathrm{~kg} / \mathrm{m}^{3}$ (mean: $0.18 \mathrm{~kg} / \mathrm{m}^{3}$ ) and $\mathrm{CBH}$ values from 4.5 to $6.5 \mathrm{~m}$. (mean: $5.25 \mathrm{~m}$ ).

Spearman's non-parametric correlation coefficient was applied to investigate the relationship between canopy fuel characteristics and stand structure parameters (Tab. IV). A strong positive correlation was found between CFL and stand basal area, and a weak positive correlation between CBD and stand basal area. The data for $\mathrm{CBH}$ and stand structure measurements failed to show any significant correlation. The correlation matrix illustrated significant correlations among the canopy fuel characteristics. CBD was highly correlated with $\mathrm{CBH}$ and CFL $(p<0.05)$. This is expected since CBD is derived from the CFL. Basal area was highly correlated with CFL $(p<0.01)$ and CBD $(p<0.05)$. This stems from the fact that higher values of stand basal area are associated with more and/or bigger trees per unit area and, therefore, higher CFL.

Tables V and VI present fire type probability and a range of active crown fire behavior potential that should be expected in uneven aged and even aged stands for each surface fuel model, according to the crown fire behavior models simulation. Even aged Aleppo pine stands with evergreen-sclerophyllous shrublands $1.5-3.0 \mathrm{~m}$ as understory presented the most severe crown fire potential, due to the heavier available surface fuel load and the higher CBD values, despite the relatively higher $\mathrm{CBH}$. The least severe crown burning conditions were observed in the uneven aged Aleppo pine stands with litter as understory, due to the reduced available surface fuel loads and the lower CBD values. Crown fireline intensity and flame length reached up to $100000 \mathrm{~kW} / \mathrm{m}$ and $53 \mathrm{~m}$, respectively. Simulations with wind speeds greater than $20 \mathrm{~km} / \mathrm{h}$ always lead to crown fire initiation regardless of the canopy and surface fuel characteristics. All simulations under extreme burning conditions resulted in crown fire initiation, as it is often reported in field observations [7]. Under moderate burning conditions both crown and surface fires were observed, depending mainly on the fuel characteristics $(\mathrm{CBH}$, surface fuel bed height, $\mathrm{CBD}$ ) of the stand. Under low burning conditions, in most cases fire spread was limited to surface fuels. Active crown fire rate of spread in Aleppo pine forests ranged from 20.3 to $62.4 \mathrm{~m} / \mathrm{min}$. No differences in the range of active crown fire spread values were found between uneven and even aged stands. This can be attributed to the fact that the crown fire spread simulation model is far more sensitive to variations in the values of the meteorological parameters (windspeed, fine fuel moisture content) than to CBD variations [25] which, in our case, were not large among the two stand types.

\section{DISCUSSION}

Canopy fuel characteristics of Aleppo pine or other coastal conifer species in Mediterranean Basin were unavailable for comparison with the results reported in this study. Therefore, North American pine species with similar canopy fuel characteristics were used for comparisons.

Cruz et al. [23] report CFL distribution for various fuel types. The mixed conifer fuel type had the highest mean value $\left(1.4 \mathrm{~kg} / \mathrm{m}^{2}\right)$, followed by Pinus contorta $\left(1.0 \mathrm{~kg} / \mathrm{m}^{2}\right)$, 

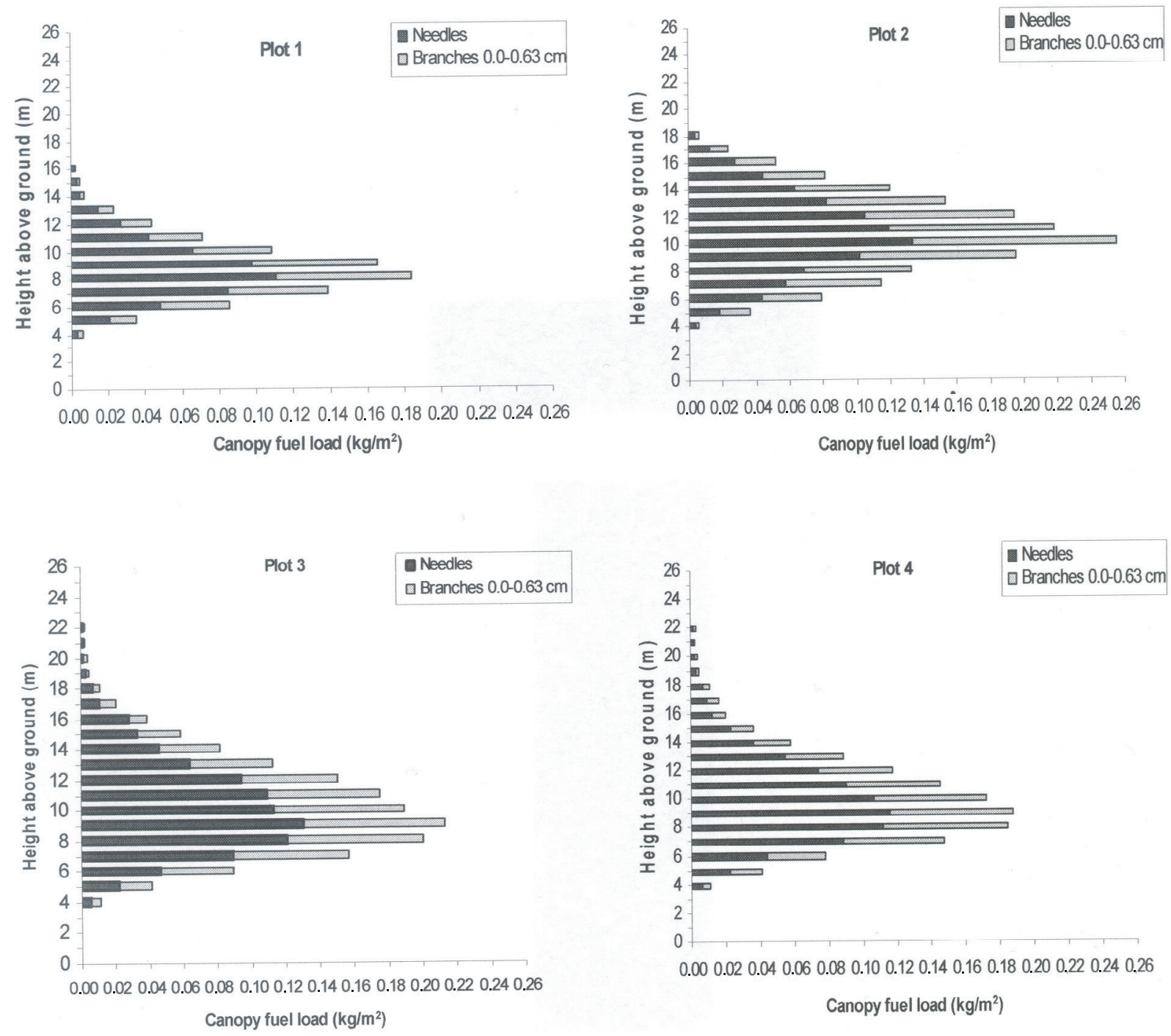

Figure 1. Canopy fuel load distribution in even aged Aleppo pine stands.

Table III. Stand and canopy fuel characteristics of the Aleppo pine plots used in the study.

\begin{tabular}{|c|c|c|c|c|c|c|c|c|}
\hline Plot & Stand structure & Canopy closure (\%) & Stem density (n/ha) & Stand height $(\mathrm{m})$ & Basal area $\left(\mathrm{m}^{2} / \mathrm{ha}\right)$ & CFL $\left(\mathrm{kg} / \mathrm{m}^{2}\right)$ & $\mathrm{CBD}^{\mathrm{a}}\left(\mathrm{kg} / \mathrm{m}^{3}\right)$ & $\overline{\mathrm{CBH}}(\mathrm{m})$ \\
\hline 1 & Even aged & 0.80 & 800 & 13.2 & 32.75 & 1.13 & 0.15 & 5 \\
\hline 2 & Even aged & 0.85 & 720 & 14.5 & 58.71 & 1.6 & 0.22 & 6.5 \\
\hline 3 & Even aged & 0.80 & 740 & 19.5 & 66.80 & 1.55 & 0.19 & 5 \\
\hline 4 & Even aged & 0.60 & 540 & 15.7 & 49.33 & 1.3 & 0.17 & 4.5 \\
\hline 5 & Uneven aged & 0.75 & 580 & 17.9 & 55.37 & 1.32 & 0.11 & 3.5 \\
\hline 6 & Uneven aged & 0.70 & 760 & 18.1 & 69.47 & 1.8 & 0.20 & 5 \\
\hline 7 & Uneven aged & 0.70 & 680 & 17.9 & 51.42 & 1.47 & 0.13 & 3 \\
\hline 8 & Uneven aged & 0.75 & 800 & 20 & 64.93 & 1.65 & 0.15 & 3.5 \\
\hline 9 & Uneven aged & 0.60 & 580 & 16.9 & 29.7 & 0.96 & 0.09 & 4 \\
\hline 10 & Uneven aged & 0.65 & 780 & 13.6 & 30.10 & 0.98 & 0.12 & 4 \\
\hline
\end{tabular}

${ }^{a}$ Effective $\mathrm{CBD}$, i.e., maximum 4-m section running mean $\mathrm{CBD}$ value. 

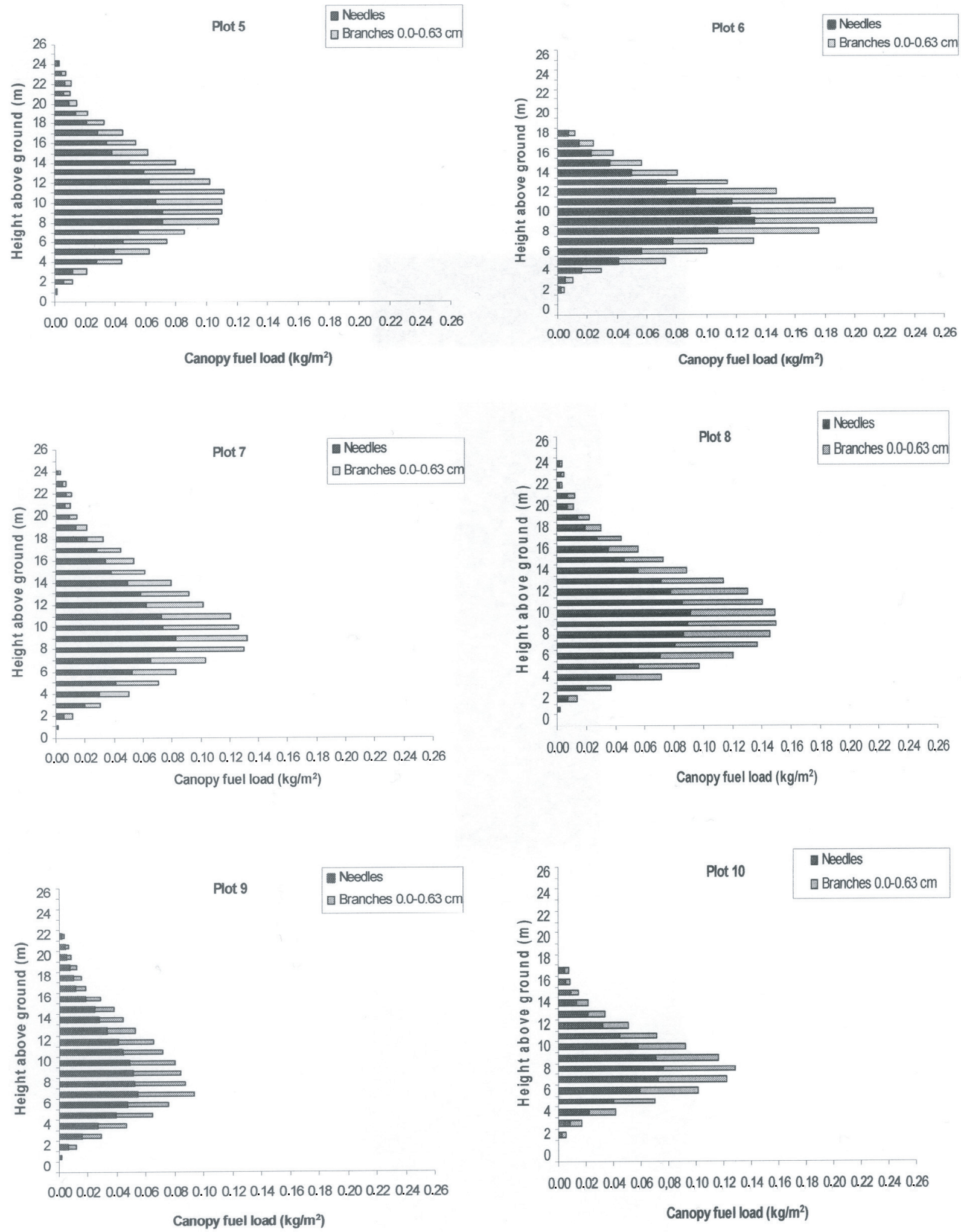

Figure 2. Canopy fuel load distribution in uneven aged Aleppo pine stands. 

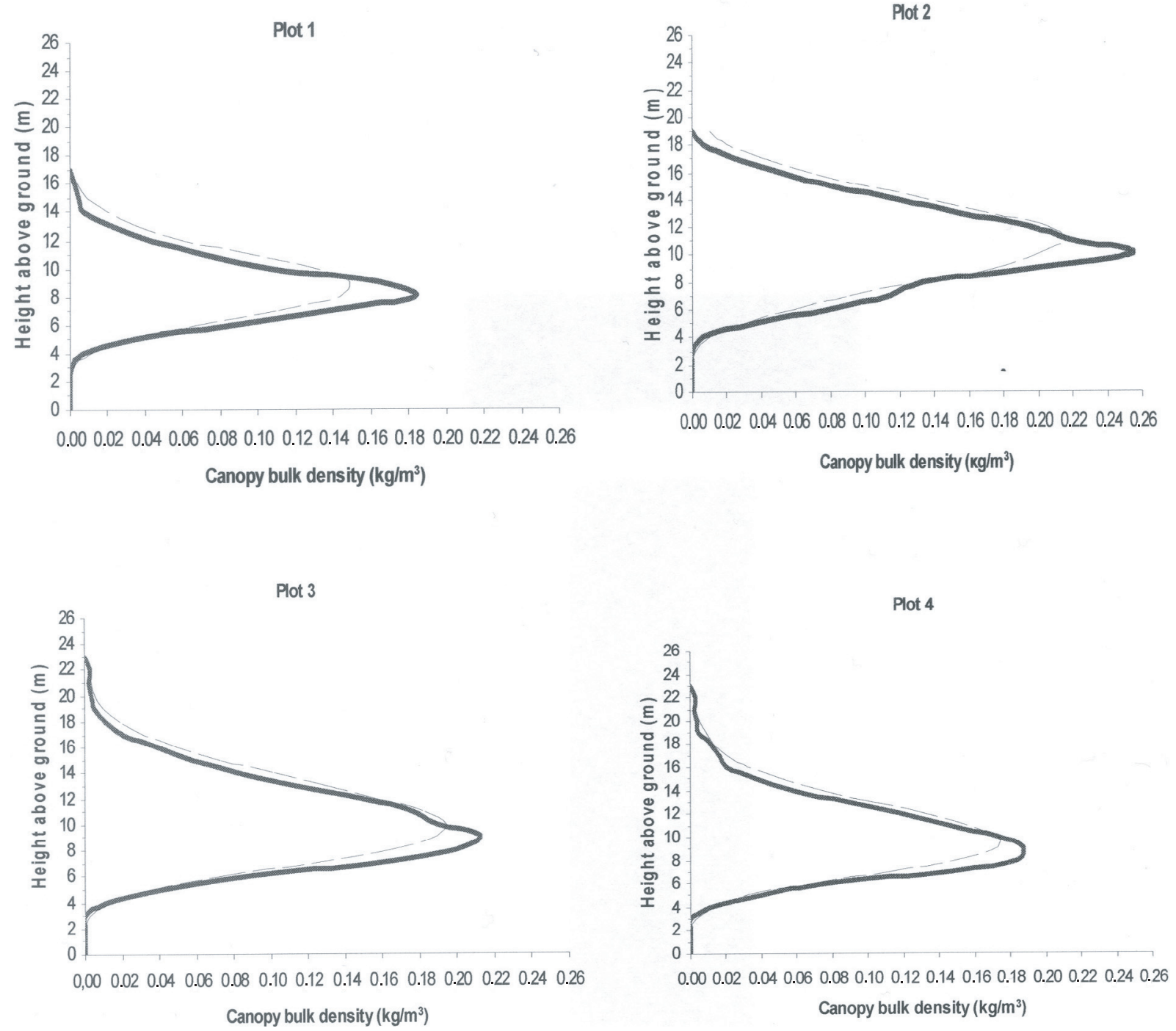

Figure 3. Canopy bulk density profiles in even aged Aleppo pine stands. Solid line is canopy bulk density; dashed line represents the 4-m running mean canopy bulk density.

Table IV. Correlation matrix between stand structure parameters and canopy fuel characteristics of Aleppo pine sampled plots.

\begin{tabular}{|c|c|c|c|c|c|c|c|}
\hline & Canopy closure & Stem density & Stand height & Basal area & $\mathrm{CFL}$ & CBD & $\mathrm{CBH}$ \\
\hline Canopy closure & 1 & & & & & & \\
\hline Stem density & 0.44 & 1 & & & & & \\
\hline Stand height & 0.05 & 0.02 & 1 & & & & \\
\hline Basal area & 0.51 & 0.23 & $0.72^{*}$ & 1 & & & \\
\hline CFL & 0.48 & 0.27 & $0.66^{*}$ & $0.95^{* *}$ & 1 & & \\
\hline CBD & 0.49 & 0.21 & 0.12 & $0.69^{*}$ & $0.71^{*}$ & 1 & \\
\hline $\mathrm{CBH}$ & 0.45 & 0.18 & -0.31 & 0.26 & 0.20 & $075^{*}$ & 1 \\
\hline
\end{tabular}

$* P<0.05 . * * P<0.01$. 

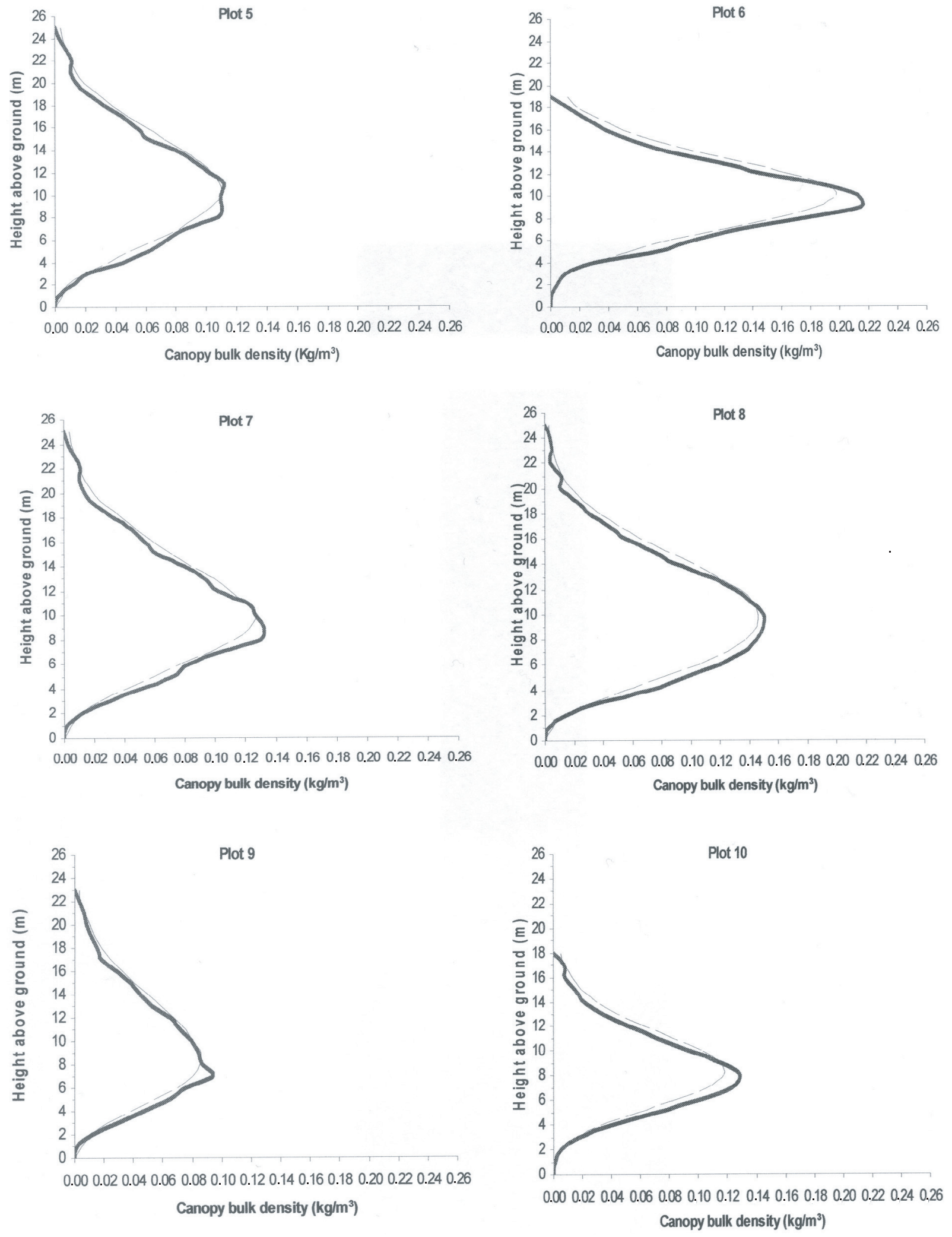

Figure 4. Canopy bulk density profiles in uneven aged Aleppo pine stands. Solid line is canopy bulk density; dashed line represents the 4-m running mean canopy bulk density. 
Table V. Fire type probabilities in Aleppo pine stands according to Van Wagner [79] crown fire spread criteria and Cruz et al. [24] crown fire initiation model ${ }^{\mathrm{a}}$.

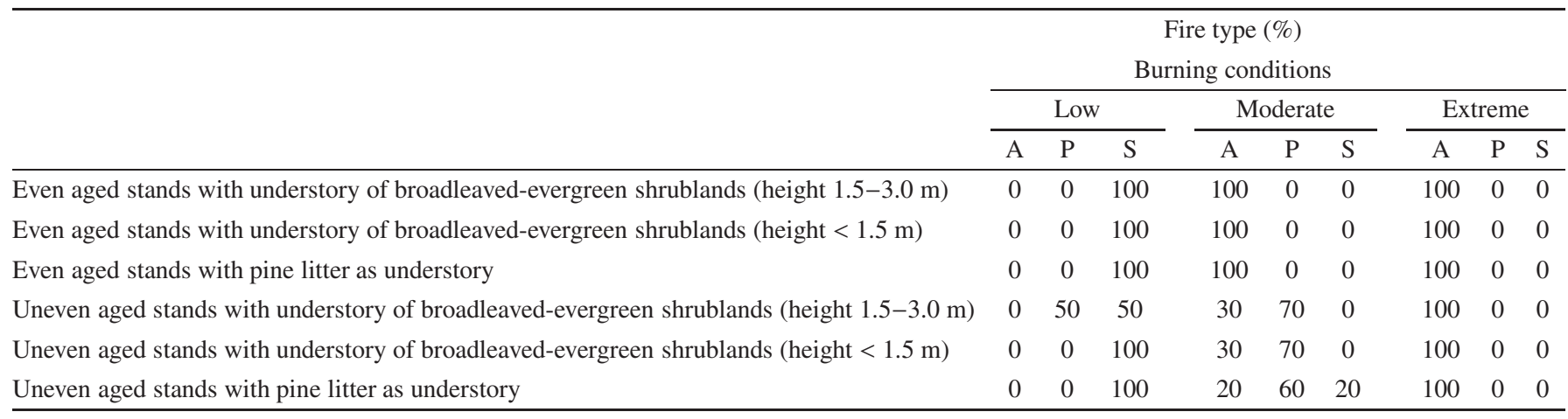

${ }^{a}$ A: Active crown fire, P: Passive crown fire, S: Surface fire.

Table VI. Potential active crown fire behavior range of Aleppo pine stands.

\begin{tabular}{|c|c|c|c|c|c|c|c|c|c|}
\hline & \multicolumn{3}{|c|}{$\begin{array}{c}\text { Rate of spread (m/min) } \\
\text { Burning conditions }\end{array}$} & \multicolumn{3}{|c|}{$\begin{array}{c}\text { Fireline intensity }(\mathrm{kW} / \mathrm{m}) \\
\text { Burning conditions }\end{array}$} & \multicolumn{3}{|c|}{$\begin{array}{l}\text { Flame length }(\mathrm{m}) \\
\text { Burning conditions }\end{array}$} \\
\hline & Low & Moderate & Extreme & Low & Moderate & Extreme & Low & Moderate & Extreme \\
\hline $\begin{array}{l}\text { Even aged stands with broadleaved-evergreen } \\
\text { shrublands (height } 1.5-3.0 \mathrm{~m} \text { ) as understory }\end{array}$ & - & $20.3-21.2$ & $58-62.4$ & - & $22168-26879$ & $85086-100339$ & - & $20-22$ & $48-52$ \\
\hline $\begin{array}{l}\text { Even aged stands with broadleaved-evergreen } \\
\text { shrublands (height }<1.5 \mathrm{~m} \text { ) as understory }\end{array}$ & - & $20.3-21.2$ & $58-62.4$ & - & $17222-22168$ & $62103-85086$ & - & $17-20$ & $39-42$ \\
\hline Even aged stands with pine litter as understory & - & $20.3-21.2$ & $58-62.4$ & - & $11388-14564$ & $38976-48439$ & - & $13-15$ & $28.5-34$ \\
\hline $\begin{array}{l}\text { Uneven aged stands with broadleaved-evergreen } \\
\text { shrublands (height } 1.5-3.0 \mathrm{~m} \text { ) as understory }\end{array}$ & - & $20.3-21.5$ & $52.6-61.3$ & - & $25334-35862$ & $74782-102248$ & - & $20.5-26$ & $43-53$ \\
\hline $\begin{array}{l}\text { Uneven aged stands with broadleaved-evergreen } \\
\text { shrublands (height }<1.5 \mathrm{~m} \text { ) as understory }\end{array}$ & - & $20.3-21.5$ & $52.6-61.3$ & - & $18940-21627$ & $49628-73284$ & - & $17-18$ & $33-42$ \\
\hline Uneven aged stands with pine litter as understory & - & $20.3-21.5$ & $52.6-61.3$ & - & $12730-14961$ & $31476-54793$ & - & $12-15$ & $25-36$ \\
\hline
\end{tabular}

-: Surface or passive crown fire resulted.

Pseudotsuga menziesii $\left(1.0 \mathrm{~kg} / \mathrm{m}^{2}\right)$ and Pinus ponderosa $\left(0.61 \mathrm{~kg} / \mathrm{m}^{2}\right)$. Alexander et al. [9] mention that the canopy fuel load of the International Crown Fire Modelling Experiment plots ranged from 0.6 to $1.5 \mathrm{~kg} / \mathrm{m}^{2}$. Scott and Reinhardt [70] give CFL values for Pinus contorta and Pinus ponderosa, 1.22 and $2.25 \mathrm{~kg} / \mathrm{m}^{2}$, respectively. The above mentioned results must be interpreted with care due to the fact that the crown fuel allometric equations that were used to estimate CFL were not developed from the same stands of the study sites. Furthermore, for some species with no published allometric equations, surrogate species were used based on similarities in tree crown structure. In the present study, the estimation of CFL was based upon specific allometric crown fuel equations developed for Aleppo pine in Greece [54].

Alexander et al. [9] give $0.16 \mathrm{~kg} / \mathrm{m}^{3}$ as a mean CBD value for the plots of the International Crown Fire Modelling Experiment. Cruz et al. [23] found similar CBD for Pinus ponderosa and Pseudotsuga menziesii (mean: $0.18 \mathrm{~kg} / \mathrm{m}^{3}$ ). High CBD values characterize the mixed conifer fuel type (mean: $0.32 \mathrm{~kg} / \mathrm{m}^{3}$ ). Pinus contorta, a species typically associated with high intensity crown fire regimes, also exhib- ited high CBD values $\left(0.28 \mathrm{~kg} / \mathrm{m}^{3}\right)$. Similar results are reported by Agee [1] for Pinus ponderosa, Pseudotsuga menziesii and Abies grandis. Scott and Reinhardt [71] measured CBD in North American conifers and report similar values with the others studies. Exception was Pinus ponderosa which exhibited high CBD $\left(0.33 \mathrm{~kg} / \mathrm{m}^{3}\right)$, due to the fact that the sampled site was in a very dense portion of a stand and the available allometric equations probably overestimated the canopy biomass. Stocks [73, 74] found low CBD values $\left(0.06-0.13 \mathrm{~kg} / \mathrm{m}^{3}\right)$ in Pinus banksiansa stands. Similar low CBD values are reported for Pinus ponderosa multi-layer stands [62]. The low CBD values in these two studies could be explained by the fact that only the needle biomass was considered as the available canopy fuel load. In view of the above, $\mathrm{CBD}$ values in the present study are realistic. The maximum CBD value of the 4-m running mean of the 1-m canopy layers that was used in this study is within the limits of the CBD values needed to model crown fire behavior [43, 70, 79]. CBD was computed using only the available canopy biomass (needles and branches $<0.63 \mathrm{~cm}$ ). This biomass aggregation best represents the fuels that are available for consumption in most 
crown fires [76]. The CBD distribution in the fuel profiles of Aleppo pine stands indicate values which would readily support the propagation of active crown fires $[1,6,25,41]$.

The CBH of the International Crown Fire Modelling Experiment plots, based on the overstory canopy, varied from 3.2 to $8.2 \mathrm{~m}$ [9]. The mean $\mathrm{CBH}$ of the immature $(4.0 \mathrm{~m})$ and mature $(12.0 \mathrm{~m})$ Pinus banksiana overstory stands $[74,75]$ is considerably greater than that of the Aleppo pine fuel complex. Cruz et al. [23] report that $\mathrm{CBH}$ for the Pinus ponderosa was significantly lower $(4.5 \mathrm{~m})$ than other typical fuel types, perhaps reflecting the low density and open structure that characterizes this fuel complex. This may also be true for Aleppo pine stands. Low density, open structure, uneven aged stands exhibit low $\mathrm{CBH}$ values due to the presence of small trees in the middlestory. Additionally, the dense broadleavedevergreen shrub understory acts as a capable ladder fuel for initiating crown fires and decreasing the fuel strata gap in Aleppo pine forests.

The CFL and CBD of Aleppo pine stands were found positively correlated with the stand basal area. As the size and/or the stem density of the trees in a stand increases, the CFL and CBD also increase due to the higher fraction of available crown fuel load. Similar results are reported by Agee [1] and Cruz et al. [23]. These studies support that stem density is also strongly correlated with canopy fuel characteristics. In the present study, stem density was not significantly correlated with canopy fuel characteristics. This could be explained by the small variability in stem density which was exhibited in the sampled plots. It should be expected that in very dense Aleppo pine stands, CFL and CBD will increase with stem density. Additional canopy fuel sampling in Aleppo pine stands could further evaluate the correlation and allow the canopy fuel characteristics estimation with regression models.

In most cases, crown fire behavior simulations indicated that crown fire transition and spread is a common feature in Aleppo pine stands. The low fuel strata gap, the heavy available surface fuel load and the substantial height of the surface fuel bed that characterize Aleppo pine fuel complexes, increase dramatically the likelihood of crown fire initiation. Active crown fire rate of spread, fireline intensity and flame length in Aleppo pine stands were found similar to values reported in typical active crown fires in the International Crown Fire Modelling Experiment, where the rate of crown fire spread ranged from 15.8 to $69.8 \mathrm{~m} / \mathrm{min}$, the fire intensity from 20000 to $100000 \mathrm{~kW} / \mathrm{m}$ and the flame front was 2-3 times the mean stand height [76]. Under extreme burning conditions, active crown fire rate of spread was even observed in Aleppo pine stands with CBD lower than Agee's threshold value $\left(0.10 \mathrm{~kg} / \mathrm{m}^{3}\right)$ [1] , as the simulation results indicated.

Crown fire initiation and rate of spread models used in this simulation are empirical. Nevertheless, they have been tested in high intensity experimental crown fires with satisfactory results [76]. Furthermore, the variability in fuel complex characteristics used during model conception and the physical fuel (CBD, fuel strata gap, surface fuel consumption) and weather (wind speed, fine fuel moisture content) parameters, should make them applicable to other conifer fuel complexes as well [20]. Additionally, wind speed is the variable that has the most influence in crown fire behavior. Wind speed is the dominant factor that affects fire behavior in Mediterranean Basin [29]. Passive crown fire characteristics were not simulated due to the lack of a validated model that predicts passive crown fire behavior.

\section{CONCLUSIONS}

This study measured the canopy fuel characteristics of Aleppo pine and it is the first of this fuel type in the Mediterranean Basin. Aleppo pine canopy fuels are distinguished by low canopy base height which, in turn, results in high probability of crown fire initiation even under moderate burning conditions. Simulation produced mostly passive crown fires in uneven aged stands, while high intensity active crown fires resulted in even aged stands due to the higher canopy bulk density and available canopy fuel load.

The characterization of Aleppo pine fuel complexes in east Mediterranean Basin as documented in this study, can be useful in the planning of fuel treatment options to reduce canopy bulk density, to increase canopy base height, to remove ladder fuels, and ultimately, to modify fire behavior in Mediterranean conifer stands and landscapes.

Crown fire behavior prediction in Aleppo pine stands can be useful in fire management, fire prevention planning or in decision making during actual fire suppression. The current crown fire behavior simulations are just a supplement to the efforts for crown fire prevention and active suppression tactics and their accuracy must be validated with real observations from wildfires burning in the field.

Acknowledgements: This study is part of Dr Ioannis Mitsopoulos' Ph.D. dissertation at the School of Forestry and Natural Environment, Aristotle University of Thessaloniki, Greece. Thanks are due to Dr. Nikolaos Nanos for useful discussions and suggestions on statistical analysis. We would also like to thank the two anonymous reviewers whose insightful comments helped to substantially improve this manuscript.

\section{REFERENCES}

[1] Agee J., The influence of forest structure on fire behavior, in: Proceedings of the 17th Annual Forest Vegetation Management Conference, January 16-18, Redding, California, 1996, pp. 52-68.

[2] Albini F.A., Wildland fires, American Scientist 72 (1984) 590-597.

[3] Albini F.A., A model for fire spread in wildland fuels by radiation, Combust. Sci. Technol. 42 (1985) 229-258.

[4] Albini F.A., Wildland fire spread by radiation - a model including fuel cooling by natural convection, Combust. Sci. Technol. 45 (1985) 101-113.

[5] Albini F.A., Stocks B.J., Predicted and observed rates of spread of crown fires in immature Jack pine, Combust. Sci. Technol. 48 (1986) 65-76.

[6] Alexander M.E., Help with making crown fire hazard assessments, in: Fischer W.C., Arno S.F. (Eds.), Protecting people and homes from wildfire in the Interior West: Proceedings of the Symposium and Workshop, 1988 October 6-8, Missoula, USDA, Forest Service, Intermountain Research Station, General Technical Report INT-251, 1988, pp.147-156. 
[7] Alexander M.E., Crown fire thresholds in exotic pine plantations in Australasia, Ph.D. thesis, Australian National University, Canberra, Australia, 1998, 228 p.

[8] Alexander M.E., Fire behaviour as a factor in forest and rural fire suppression, Forest Research, Rotorua, in association with the New Zealand Fire Service Commission and National Rural Fire Authority, Wellington, Forest Research Bulletin No. 197, Forest and Rural Fire Scientific and Technical Series, Report No. 5, 2000, 28 p.

[9] Alexander M.E., Stefner C.N., Mason J.A., Stocks B.J., Hartley G.R., Maffey M.E., Wotton B.M., Taylor S.W., Lavoie N., Dalrymple G.N., Characterizing the jack pine-black spruce fuel complex of the International Crown Fire Modelling Experiment (ICFME), Natural Resources Canada, Forestry Service, Northern Forestry Centre, Edmonton, Alberta. Information Report NOR-X393, 2004, 49 p.

[10] Anderson H.E., Aids to determining fuel models for estimating fire behavior, USDA, Forest Service, Intermountain Forest and Range Experiment Station, Research Paper INT-122, Ogden, Utah, 1982, $22 \mathrm{p}$.

[11] Andrews P.L., BEHAVE: fire behavior prediction and fuel modeling system-BURN subsystem part I, USDA, Forest Service, Intermountain Forest and Range Experiment Station, General Technical Report, INT-260, Ogden, Utah, 1986, 130 p.

[12] Andrews P.L., Bevins C.D., Seli R.C., BehavePlus fire modeling system, version 3.0: User's Guide, USDA, Forest Service, Rocky Mountain Research Station, General Technical Report RMRSGTR-106, Ogden, Utah, 2005, 142 p.

[13] Baldwin V.C. Jr., Peterson K.D., Burkhart H.E., Amatais R.L., Dougherty P.M., Equation for estimating loblolly pine branch and foliage weight and surface area distributions, Can. J. For. Res. 27 (1997) 918-927.

[14] Barbero M., Loisel R., Quézel P., Richardson D.M., Romane F., Pines of the Mediterranean Basin, in: Richardson D.M. (Ed.), Ecology and biogeography of Pinus, Cambridge University Press, Cambridge, 1998, pp 153-170.

[15] Brown J.K., Weight and Density of Crowns of Rocky Mountains Conifer, USDA, Forest Service, Intermountain Forest and Range Experiment Station, Research Paper INT-197, Ogden, Utah, 1978, $56 \mathrm{p}$.

[16] Burgan R.E., Rothermel R.C., BEHAVE: Fire prediction and fuel modeling system-FUEL subsystem, USDA Forest Service General Technical Report INT-167, Ogden, Utah, 1984, 126 p.

[17] Butler B.W., Finney M.A., Andrews P.L., Albini F.A., A radiation driven model for crown fire spread, Can. J. For. Res. 34 (2004) 1588-1599.

[18] Byram G.M., Combustion of forest fuels, in: Davis K.P. (Ed.), Forest fire: control and use, New York, McGraw Hill Book Co, 1959, pp. 61-89.

[19] Call P., Albini F.A., Aerial and surface consumption in crown fires, Int. J. Wildl. Fire 7 (1997) 259-264.

[20] Cruz M.G., Modeling the initiation and spread of crown fires, M. Sci. thesis, University of Montana, Missoula, 1999, 162 p.

[21] Cruz M.G., Ignition of crown fuels above a spreading surface fire, Ph.D. dissertation, University of Montana, Missoula, 2004, 126 p.

[22] Cruz M.G., Alexander M.E., Wakimoto R.H., Predicting crown fire behavior to support forest fire management decision making, in: Viegas D.X. (Ed.), Forest fire research and wildland fire safety, Proceedings of the IV International Conference on Forest Fire Research, Millpress Scientific Publications, Rotterdam, 2002, pp. $1-10$.

[23] Cruz M.G., Alexander M.E., Wakimoto R.H., Assessing canopy fuel stratum characteristics in crown fire prone fuel types of western North America, Int. J. Wildl. Fire 12 (2003) 39-50.

[24] Cruz M.G., Alexander M.E., Wakimoto R.H., Modeling the likelihood of crown fire occurrence in conifer forest stands, For. Sci. 50 (2004) 640-658
[25] Cruz M.G., Alexander M.E., Wakimoto R.H., Development and testing of models for predicting crown fire rate of spread in conifer forest stands, Can. J. For. Res. 35 (2005) 1626-1639.

[26] Dimitrakopoulos A.P., PYROSTAT - a computer program for forest fire data inventory and analysis in Mediterranean countries, Environ. Model. Softw. 16 (2001) 351-359.

[27] Dimitrakopoulos A.P., Mediterranean fuel models and potential fire behavior in Greece, Int. J. Wildl. Fire 11 (2002) 127-130.

[28] Dimitrakopoulos A.P., Panov P.I., Pyric properties of some dominant Mediterranean vegetation species, Int. J. Wildl. Fire 10 (2001) 23-27.

[29] Dimitrakopoulos A.P., Dritsa S., Novel nomographs for fire behavior prediction in Mediterranean and submediterranean vegetation types, Forestry 76 (2003) 479-490.

[30] Dupuy J., Morvan D., Numerical study of a crown fire spreading toward a fuel break using a multiphase physical model, Int. J. Wildl. Fire 14 (2005) 141-151.

[31] Finney M.A., FARSITE: Fire area simulator-model development and evaluation, USDA, Forest Service, Rocky Mountain Research Station, Research Paper RMRS-RP-4, Ogden, Utah, 1998, 47 p.

[32] Forestry Canadian Fire Danger Group, Development and Structure of the Canadian Forest Fire Behavior Prediction System, Forestry Canada, Science and Sustainable Development Directorate, Information Report ST-X-3, Ottawa, Canada, 1992, 65 p.

[33] Fule P.Z., Covington W.W., Smith H.B., Springer J.D., Heinlein T.A., Huisinga K.D., Moore M.M., Comparing ecological restoration alternatives: Grand Canyon, Arizona, For. Ecol. Manage. 170 (2002) 19-41.

[34] Gonzalez J.R., Pukkala T., Palahi M., Optimizing the management of Pinus sylvestris L. stand under risk of fire in Catalonia (north-east of Spain), Ann. Sci. For. 62 (2005) 493-501.

[35] Gonzalez J.R., Palahi M., Trasobares A., Pukkala T., A fire probability model for forest stands in Catalonia (north-east Spain), Ann. For. Sci. 63 (2006) 169-176.

[36] Graham R.T., Hayman fire case study, USDA, Forest Service, Rocky Mountain Research Station, General Technical Report RMRS-GTR-114, Fort Collins, 2003, 396 p.

[37] Grigal D.F., Kernik L.K., Generality of black spruce biomass estimation equations, Can. J. For. Res. 14 (1984) 486-490.

[38] Grishin A. M., Perminov V. A., Mathematical modeling of the ignition of tree crowns, Combust. Explos. Shock Waves 34 (1998) $378-376$

[39] Johnson A., Woodard P., Titus S., Lodgepole pine and white spruce fuel weights predicted from height and crown width, Can. J. For. Res. 19 (1989) 527-530.

[40] Johnson A., Woodard P., Titus S., Lodgepole pine and white spruce crown fuel weights predicted from diameter at breast height, For. Chron. 66 (1990) 596-599.

[41] Johnson E.A., Fire and vegetation dynamics: Studies from the North American boreal forest, Cambridge University Press, 1992, 129 p.

[42] Keane R.E., Burgan R., Wangtendonk J., Mapping wildland fuels for fire management across multiple scales: Integrating remote sensing, GIS, and biophysical modeling, Int. J. Wildl. Fire 10 (2001) 301-319.

[43] Keane R.E., Reinhardt E.D., Scott J., Gray K., Reardon J., Estimating forest canopy bulk density using six indirect methods, Can. J. For. Res. 35 (2005) 724-739.

[44] Keyes C.R., O’Hara K.L., Quantifying stand targets for silvicultural prevention of crown fires, West. J. Appl. For. 17 (2002) 101-109.

[45] Kilgore B.M., Sando R.W., Crown fire potential in a sequoia forest after prescribed burning, For. Sci. 21 (1975) 83-87.

[46] Kittredge J., Estimation of the amount of foliage of trees and stands, J. For. 42 (1944) 905-912. 
[47] Lemmon P.E., A spherical densiometer for estimating forest overstory density, For. Sci. 1 (1956) 314-320.

[48] Linn R.R., Transport model for prediction of wildfire behavior, Los Alamos National Laboratory, Scientific Report, 1997, 195 p.

[49] Linn R.R., Reisner J., Colman J.J., Winterkamp J., Studying wildfire behavior using FIRETEC, Int. J. Wildland Fire 11 (2002) 233-246

[50] Linn R.R., Winterkamp J., Colman J.J., Edminster, C., Bailey J.D., Modeling interactions between fire and atmosphere in discrete element fuel beds, Int. J. Wildl. Fire 14 (2005) 37-48.

[51] Long J.N., Smith F.W., Leaf-area sapwood area relations of lodgepole pine as influenced by stand density and site index, Can. J. For. Res. 18 (1988) 247-250.

[52] McAlpine R.S., Hobbs M.W., Predicting the height to live crown base in plantation of four boreal forest species, Int. J. Wildl. Fire 4 (1994) 103-106.

[53] Mead B.R., Phytomass in southeast Alaska, US Department of Agriculture, Forest Service, Pacific Northwest Research Station, Research Paper, PNW-RP-505, Portland, OR, 1998, 48 p.

[54] Mitsopoulos I.D., Crown fire analysis and management in Pinus halepensis forests of Greece, Ph.D. dissertation, Aristotle University of Thessaloniki, 2005, 232 p. (in Greek, with English abstract).

[55] Moeur M., Crown width and foliage weight of northern Rocky Mountain conifers, USDA, Forest Service, Intermountain Forest and Range Experiment Station, Ogden, Utah, Research Paper INT283, 1981, 14 p.

[56] Monserud R.A., Marshall J.D., Allometric crown relations in three northern Idaho conifer species, Can. J. For. Res. 29 (1999) $521-535$.

[57] Moreno J.M., Oechel W.C., The role of fire in Mediterranean-type ecosystems, Springer-Verlag, New York, NY, 1994.

[58] Norusis M.J., SPSS professional statistics, SPSS Inc., Chicago, 1997, $376 \mathrm{p}$.

[59] Otrmar R.D., Vilnanek R.E., Wright C.S., Stereo photoseries for quantifying natural fuels, Vol. I: Mixed conifer with mortality, Western Juniper, Sagebrush and grasslands types in the Interior Pacific Northwest, PMS 830, NFES 2580, Boise, Idaho: National Wildfire Coordinating Group, National Interagency Fire Center, $1998,73 \mathrm{p}$

[60] Pastor E., Zarate L., Planas E., Arnaldos J., Mathematical models and calculation systems for the study of wildland fire behavior, Prog. Energy Combust. Sci. 29 (2003) 139-153.

[61] Perez B., Cruz A., Fernandes-Gonzales F., Moreno J.M., Effects of the recent land-use history on the postfire vegetation of an uplands in Cental Spain, For. Ecol. Manage. 182 (2003) 273-283.

[62] Perry D.A., Jing H., Youngblood A., Oetter D.R., Forest structure and fire susceptibility in volcanic landscapes of the eastern high Cascades, Oregon, Conserv. Biol. 18 (2004) 913-926.

[63] Porterie B., Loraud J.C., Bellemare I.O., Consalvi J.L., A physically based model of the onset of crowning, Combust. Sci. Technol. 175 (2003) 1109-1141

[64] Quezel P., Taxonomy and biogeography of Mediterranean pine species, in: Ne'eman G., Trabaud L. (Eds.), Ecology, biogeography and management of Pinus halepensis and Pinus brutia forest ecosystems in the Mediterranean Basin, Backhuys Publishers, Leiden, 2000, pp. 1-12.

[65] Riano D., Meier E., Allgower B., Chuevico E., Ustin S., Modeling airborne laser scanning data for the spatial generation of critical forest parameters in fire behavior modeling, Remote Sens. Environ. 86 (2003) 177-186.
[66] Riano D., Chuevico E., Condes S., Gonzales-Matesanz J., Ustin S., Generation of crown bulk density for Pinus sylvestris L. from lidar, Remote Sens. Environ. 92 (2004) 345-352.

[67] Rothermel R.C., A mathematical model for predicting fire spread in wildland fuels, USDA, Forest Service, Intermountain Forest and Range Experiment Station, Research Paper INT-115, Ogden, Utah, 1972, 40 p.

[68] Rothermel R.C., Predicting behavior and size of crown fires in the Northern Rocky Mountains, USDA, Forest Service Intermountain Research Station, Research Paper INT-438, 1991, 46 p.

[69] Sando R., Wick C., A method of evaluating crown fuels in boreal stands, USDA, Forest Service, North Central Forest Experiment Station, Research Paper NC-84, 1972, 26 p.

[70] Scott J.H., Reinhardt E.D., Assessing crown fire potential by linking models of surface and crown fire potential, USDA, Forest Service, Rocky Mountain Research Station, Research Paper RMRS-29, Fort Collins, USA, 2001, 59 p.

[71] Scott J.H., Reinhardt E.D., Estimating canopy fuels in conifer forests, Fire Management Today 62 (2002) 45-50.

[72] Stephens S.L., Evaluation of the effects of silvicultural and fuels treatments on potential fire behavior in Sierra Nevada mixed conifer forests, For. Ecol. Manage. 105 (1998) 21-35.

[73] Stocks B.J., Black spruce fuel weights in northern Ontario, Can. J. For. Res. 10 (1980) 498-501.

[74] Stocks B.J., Fire behavior in immature jack pine, Can. J. For. Res. 17 (1987) 80-86.

[75] Stocks B.J., Fire behavior in mature jack pine, Can. J. For. Res. 19 (1989) 783-790.

[76] Stocks B.J., Alexander M.E., Wotton B.M., Stefner C.N., Flannigan M.D., Taylor S.W., Lavoie N., Mason J.A., Hartley G.R., Maffey M.E., Dalrymple G.N., Blake T.W., Cruz M.G., Lanoville R.A., Crown fire behaviour in a northern jack pine-black spruce forest, Can. J. For. Res. 34 (2004) 1548-1560.

[77] Terradas J., Pinol J., Lloret F., Risk factors in wildfires along the Mediterranean coast of the Iberian Peninsula, in: Trabaud L. (Ed.), Fire management and landscape ecology, International Association of Wildland Fire, Fairfield, Washington, USA, 1998, pp. 297-304.

[78] Thomas P.H., The size of flames from natural fires, in: Proceedings of 9th International Symposium on Combustion Processes, Academic Press, New York, 1963, pp. 844-859.

[79] Van Wagner C.E., Conditions of the start and spread of crown fires, Can. J. For. Res. 7 (1977) 23-34.

[80] Van Wagner C.E., Prediction of crown fire behavior in conifer stands, in: MacIver D.C., Auld H., Whitewood R. (Eds.), Proceedings at the 10th Conference on Fire and Forest Meteorology, Ottawa, Canada, 1989, pp. 207-212

[81] Van Wagner C.E., Prediction of crown fire behavior in two stands of jack pine, Can. J. For. Res. 23 (1993) 442-449.

[82] Williams D.F., Influence of quantity, distribution and moisture content of forest fuels on fire management of radiata pine plantations, Master of Science thesis, University of Melbourne, Victoria, Australia, 1977, $188 \mathrm{p}$.

[83] Wilson J., Baker P., Mitigating fire risk to late-successional forest reserves on the east slope of the Washington Cascade Range, For. Ecol. Manage. 110 (1998) 59-75.

[84] Xanthopoulos G., Development of a wildland crown fire initiation model, Ph.D. thesis, University of Montana, Missoula, 1990, 152 p. 